\title{
EVALUASI PROGRAM SOSIALISASI CIVIC LITERACY DALAM PEMBENTUKAN ETIKA WARGANEGARA MUDA
}

\author{
Armaidy Armawi \\ Universitas Gadjah Mada Yogyakarta \\ Email: armaidy@ugm.ac.id
}

\section{Raharjo}

Universitas Sebelas Maret Surakarta

\section{Abstrak}

Tujuan penelitian ini untuk mengetahui dan mengevaluasi proses sosialisasi civic literacy dalam pembentukan etika warganegara muda di Kota Surakarta serta merumuskan model sosialisasi civic literacy sebagai bentuk pendidikan kewarganegaraan kemasyarakatan (citizenship education). Penelitian ini dilaksanakan di Kota Surakarta dengan sasaran komunitas yang melakukan kegiatan sosialisasi materi kewarganegaraan di lingkungan masyarakat. Jenis penelitian ini ialah penelitian lapangan yang menggunakan pendekatan kualitatif deskriptif yang mendeskripsikan praktik pendidikan kewarganegaraan secara informal di masyarakat berupa kegiatan sosialisasi civic literacy. Hasil penelitian menunjukkan bahwa sosialisasi civic literacy dilakukan secara informal dengan pembiasaan, pengembangan, dan pembelajaran secara berkelanjutan memiliki tujuan untuk membentuk etika warganegara berperspektif ketahanan pribadi. Penelitian ini juga menghasilkan suatu model civic literacy sebagai perencanaan dalam proses pembelajaran yang berisi informasi tentang bagaimana menjadi warganegara yang beretika, paham hak dan kewajibannya, memiliki rasa tanggung jawab dan rasa cinta tanah air yang diimplementasikan dalam kehidupan bermasyarakat, berbangsa dan bernegara.

Kata kunci: Evaluasi, Civic literacy, Etika warganegara. 


\section{Abstract}

This study aims to find out and evaluate the process of civic literacy socialization to establish the ethics of young citizens and the implications towards personal resilience in Surakarta and formulating the socialization model of civic literacy as a form of citizenship education. This research was conducted in Surakarta with the target of community conducting citizenship education activities. This research used field research with descriptive qualitative approach which describes citizenship education practice which is done informally in socialization of civic literacy activities. The results showed that the socialization of civic literacy was done informally with habituation, development, and learning which was done continuously and had the objective to form the ethics of citizens with the perspective of personal resilience. This research also produces a model of civic literacy as a planning in the learning process which contains information about how to be an ethical citizen, understand the rights and obligations, have a sense of responsibility and nationalism that is implemented in the life of society, nation and state.

Keywords: Evaluation, Civic literacy, Citizenship ethics.

\section{PENDAHULUAN}

Setiap negara bangsa (nation state) memiliki generasi muda yang diharapkan dapat menggantikan peran kepemimpinan generasi sebelumnya. Hal ini dikenal dengan istilah generasi muda yang menjadi calon generasi penerus bangsa pada saatnya nanti. Wajar saja jika suatu bangsa memiliki harapan tinggi terhadap generasi muda, karena pada akhirnya, generasi muda inilah yang akan mengambil alih estafet kepemimpinan dalam sebuah negara. Namun begitu, seringkali harapan itu dihadapkan pada kondisi yang anomali, misalnya permasalahan tentang kepemudaan yang semakin hari semakin berkembang dan kompleks. "Permasalahan yang paling jamak ialah generasi muda dianggap kurang peduli terhadap bangsa dan masalah klasik seperti pergaulan bebas, narkoba, dan konflik antar pemuda (Astuti, 2015).

Konsekuensi logis bagi setiap negara bangsa yang ingin tetap eksis, yaitu menjaga dan mendidik generasi penerusnya, 
menyiapkan generasi muda untuk berpartisipasi dalam kehidupan bermasyarakat. Namun, di Indonesia masih belum dapat mencapai tingkat pemahaman dan penerimaan terhadap kewajiban dan hak serta tanggung jawab sebagai warganegara dalam kehidupan demokratis (Budimansyah, 2008: 11-12). Alexis de Toqueville (Branson, 1999: 2) menjelaskan bahwa:

"Generasi baru ialah orang yang baru pula dan harus memperoleh pengetahuan yang mantap, mempelajari sebuah keterampilan, dan mengembangkan sikap baik atau karakter baik pribadi dan publik yang mendasari demokrasi konstitusional. Hal ini harus terus dipupuk karena demokrasi bukanlah sebuah mesin yang berjalan sendiri, melainkan perlu ada penggerak yang sadar dan menyiapkan dari generasi ke generasi".

Penjelasan tersebut menegaskan bahwa generasi merupakan calon masyarakat baru yang akan melanjutkan estafet kehidupan bermasyarakat, bangsa, dan negara yang seharusnya dapat memperoleh pengetahuan serta mempelajari segala keahlian terutama terkait dengan keahlian dalam memahami dan mempraktikkan karakter publik dan karakter privat. Pembinaan terhadap warganegara, khususnya warganegara muda sebagai generasi calon penerus bangsa ini sepatutnya menjadi perhatian yang utama.

Salah satu proses tersebut dapat dilakukan melalui lembaga formal maupun informal. Lembaga formal sudah terstruktur dalam sebuah institusi dan kurikulum yang dikenal dengan sekolah. Pembinaan karakter warga negara melalui sekolah merupakan kewajiban setiap negara dan hak setiap warganegara. Namun begitu, tidak menutup kemungkinan lembaga-lembaga informal juga melakukan aksi tersendiri untuk pembinaan terhadap warga negara, khususnya warganegara muda. Untuk itu, perlu adanya wawasan kebangsaan bagi warganegara, yang dapat dimulai 
dengan memperdalam kajian kewarganegaraan dalam bidang civic literacy. Beberapa komponen inti dalam civic literacy ini yaitu pengetahuan kewarganegaraan, keterampilan kewarganegaraan, dan sikap kewarganegaraan. Berangkat dari perspektif integrasi politik, "civic literacy merupakan aspek penting dalam mengembangkan perilaku integratif yang berkontribusi secara positif terhadap integrasi bangsa dan integrasi elit dengan rakyat" (Cholisin, 2010: 1). Dalam kajian ini, kegiatan sosialisasi civic literacy merupakan salah satu kegiatan nyata dalam rangka mewujudkan hal tersebut. Pokok bahasan kajian ini tentang sosialisasi civic literacy dalam pembentukan etika warganegara muda di Kota Surakarta. Adapun rumusan masalah dapat diajukan sebagai berikut, bagaimana program sosialisasi civic literacy dalam pembentukan etika warganegara muda di Kota Surakarta?, dan bagaimana evaluasi program sosialisasi civic literacy dalam pembentukan etika warganegara muda di Kota Surakarta?

Nuryadi (2010) melakukan penelitian dengan judul "Peran Nilai-Nilai Dalam Kurikulum Pendidikan Kewarganegaraan Untuk Membentuk Masyarakat Madani dan Implikasinya Terhadap Ketahanan Sosial", menjelaskan tentang peran nilai-nilai dalam kurikulum pendidikan kewarganegaraan untuk pembentukan masyarakat madani ditunjukkan dengan adanya tujuan pendidikan kewarganegaraan untuk membentuk "good citizen", warganegara yang tahu dan mau melaksanakan kewajiban serta hak nya. Data ini didukung dengan beberapa materi yang mendukung dalam Pendidkan Kewarganeraan yaitu persatuan dan kesatuan bangsa, Norma hukum dan peraturan, HAM, Kebutuhan warganegara, Konstitusi Negara, Kekuasaan dan Politik, Pancasila, dan Globalisasi.

Selanjutnya, penelitian Ch. Baroroh\& Machmud Al Rasyid (2015) dengan judul "Constitutional Question Sebagai Model Pembelajaran Kritis Untuk Pengembangan Civic literacy Calon Guru Dalam Rangka Pembentukan Living Constitution" memaparkan bahwa constitutional question dapat digunakan dalam proses pembelajaran sebagai model pembelajaran kritis dengan tujuan 
untuk pengembangan civic literacy. Adanya pengembangan civic literacy yang dilakukan melalui proses model pembelajaran kritis, membentuk suatu persepsi dan wawasan mengenai kehidupan konstitusi dalam suatu negara, memberikan pemahaman bahwa setiap warganegara memiliki hak untuk berpikir dan bertindak kritis mengenai kehidupan konstitusi negara, sehingga pada akhirnya dapat terwujud living constitution.

Merujuk pada hasil-hasil penelitian di atas, peneliti tertarik untuk mengkaji tentang civic literacy, khususnya terkait dengan kajian evaluasi program sosialisasi civic literacy dalam pembentukan etika warganegara muda.

\section{Konsep Evaluasi Program}

Evaluasi program merupakan "kegiatan dengan maksud mengetahui tingkat keberhasilan dari rencana yang sudah disusun" (Arikunto, 1993: 297). Tyler (1950) (dalam Suharsimi Arikunto dan Cepi Safruddin Abdul Jabar, 2009: 5), memaparkan bahwa "dalam dunia pendidikan evaluasi program dilakukan untuk mengetahui keberhasilan tujuan pendidikan". Cronbach (1963) \& Stufflebeam (1971) (dalam Suharsimi Arikunto dan Cepi Safruddin Abdul Jabar (2009: 5), mengatakan "evaluasi sebuah program ialah sebuah upaya untuk menyampaikan informasi kepada pemangku kebijakan atau pengambil keputusan yang berisi data-data proses pelaksanaan program, kekurangan dan kelebihan kegiatan, sehingga dapat digunakan untuk pengambilan keputusan atau kebijakan selanjutnya". Hasil dari laporan evaluasi berisi informasi yang objektif sehingga keputusan yang diambil berikutnya dapat bersifat objektif pula.

\section{Teori Sosialisasi}

Tentang konsep sosialisasi, Ihrom (2004: 30) mengutip David A. Goslin, menjelaskan bahwa "Sosialisasi ialah sebuah proses aktivitas yang dialami seseorang dalam memperoleh pengetahuan, keterampilan, nilai-nilai (values), dan norma yang menjadi dasar 
untuk bertindak atau berpartisipasi dalam suatu kelompok masyarakat". Peter Berger juga memaparkan pendapat yang tidak jauh berbeda, yaitu mengenai sosialisasi yang diterjemahkan sebagai "suatu proses seorang anak belajar menjadi seorang anggota yang mampu berpartisipasi dalam masyarakat" (Peter 2003: 39). Konsep ini dapat diterjemahkan dalam bahasa yang lebih sederhana dan terstruktur, bahwa sosialisasi merupakan sebuah proses melaksanakan ide, dan proses atau seperangkat aktivitas-aktivitas baru dengan harapan orang lain dapat menerimanya dan melakukan penyesuaian terhadap partisipasi masyarakat di kelompoknya.

\section{Konsep Civic Literacy}

Civic literacy atau dapat dikatakan sebagai sebuah kemelekwacanaan dalam konteks kewarganegaraan yang diterjemahkan secara istilah yaitu sebuah pengetahuan serta kemampuan seorang warga dalam proses pemecahan masalah sosial, politik, dan masalah kenegaraan (Suryadi, 2010: 30). Kajian ilmu kewarganegaraan menempatkan civic literacy pada konteks dasar kebajikan politik seorang warganegara (political virtue of citizenship). Civic literacy itu sendiri secara implisit menunjukkan sebuah bentuk penguasaan seorang warganegara pada khususnya dan pada umumnya ialah yang dimanifestasikan dalam sebuah aktivitas kewarganegaraan (Suryadi, 2010: 29-30). Dwipayana (2013: 3) memaparkan bahwa civic literacy dapat dipahami sebagai "sebuah kapasitas pengetahuan serta kemampuan seorang warganegara untuk dapat memahami dunia politiknya, atau secara lebih luas dapat pula dipahami sebagai suatu kapasitas pengetahuan mengenai bagaimana aktivitas partisipasi yang dapat dilakukan untuk memulai sebuah perubahan dalam masyarakat atau komunitas kelompoknya di taraf yang lebih besar/luas". pada prinsipnya, civic literacy dapat dimanfaatkan sebagai tools dan sekaligus tujuan untuk mencapai sesuatu yang diperkuat oleh pilihan kebajikan (Suryadi, 2010: 32). 
Civic literacy dalam konteks kewarganegaraan, sangat erat kaitannya dengan pembahasan teori Civics. Civics itu sendiri merupakan suatu ilmu yang membahas tentang sebuah kewajiban dan hak yang melekat pada warganegara (Wuryan dan Syaifullah, 2008: 36). Untuk dapat melaksanakan kewajiban dan haknya sesuai dengan yang seharusnya dan sebagaimana mestinya, seorang warganegara atau sekelompok warganegara harus tahu, dan juga paham, serta melakukan pengamalan tentang hal-hal apa yang menjadi kewajibannya ataupun haknya sebagai warganegara.

Progresifnya konseptualisasi civic literacy, membuat kajian ini berkembang menjadi hal yang sangat penting bagi warganegara, utamanya bagi warganegara muda yang tersemat sebagai generasi penerus bangsa. Sebuah proses penguasaan civic literacy pada akhirnya ialah pembentukan warga negara yang baik (good citizen) yang memiliki etika dan karakter yang sesuai dengan nilai-nilai yang hidup di lingkungan Indonesia. Warga negara yang baik (good citizen) dan beretika, dewasa ini sangat dibutuhkan bagi kemajuan dan perkembangan warganegara dalam kehidupan berbangsa, bermasyarakat dan bernegara.

\section{Etika Warganegara Muda}

Warganegara menurut Azra (2003: 74) adalah “bangsa Indonesia yang asli dan juga bangsa lain yang secara hukum disahkan undang-undang sebagai warganegara". Konsep-konsep mengenai citizen, hak, kota, peradaban, dan urban ini tidak bisa dilepaskan dari apa yang berkembang di Yunani kuno yang memang menjadi cikal bakal berkembangnya konsep tersebut di dunia Barat. Oleh karena itu, perlu sekali untuk diketahui konsep warganegara.

Mengenai konsep warganegara muda, pada prinsipnya adalah sesuai dengan UU No. 40 Tahun 2009 tentang Kepemudaan, di mana pemuda adalah warganegara dengan usia 16-30 tahun. Mengenai pembahasan warga negara muda, merujuk pada pemahaman umum tentang pemuda yang dijelaskan sebagai waktu 
transisi dalam kehidupan dari masa kanak-kanak menuju dewasa, transisi dari keadaan ketergantungan masa kecil menuju kemandirian saat dewasa. Fase kehidupan ini disertai transisi dalam fisiologis, hukum, psikologis, dimensi ekonomi dan kehidupan sosial di masyarakat (United Nations Population FundUNFPA Indonesia, 2014: 3).

Terkait dengan etika warganegara muda, bahwa etika berarti "sebuah pengetahuan yang membahas baik-buruk atau benartidaknya tingkah laku manusia". Ethics asal mulai kata etika, pada prinsipnya memiliki arti sebenarnya yaitu "kebiasaan". Namun, seiring berjalannya waktu, pemaknaan etika berkembang. Saat ini, etika dimaknai sebagai suatu bidang ilmu yang mengkaji permasalahan perbuatan dan atau tingkah laku manusia, baik secara pribadi maupun dalam konteks relasi dengan negara yang dapat dinilai baik dan mana yang dapat dinilai buruk dengan memperlihatkan amal perbuatan manusia sejauh yang dapat dicerna akal pikiran (Rahmaniyah, 2010: 58). Dengan demikian, etika warganegara muda merupakan suatu sikap etik yang mengandung nilai-nilai (values) yang dimiliki oleh warga negara muda dalam menjalan kehidupan bermasyarakat, berbangsa dan bernegara. Etika warga negara muda ini tidak lepas dari konsep citizenship ethich. Seperti yang dijelaskan oleh Adeney (1988: 15) yang membedakan antara konsep "citizenship ethics dan public ethics. Adeney menegaskan bahwa "etika kewarganegaraan berbeda dari etika publik". Etika publik berisi tentang diskursus kebaikan dari suatu komunitas dan tentang dasar dari sebuah gagasan. Sedangkan kajian etika kewarganegaraan diterjemahkan sebagai sebuah peranan dari warganegara untuk mencapai kebaikan tersebut. Etika publik yang cenderung spesifik memaparkan mengenai kebaikan pada umumnya dan menjelaskan bagaimana kebaikan itu dapat dicapai, serta mengevaluasi pencapaian itu bagi masyarakat secara keseluruhan. "Etika publik lebih cenderung memberi arah dan persetujuan atau sebuah kesepakatan yang dapat memonitor tindakan warga atau individu" (Ruhulessin, 2019: 188189). 
Pendekatan yang dilakukan dalam penelitian ini ialah metode penelitian lapangan dan termasuk jenis penelitian deskriptif kualitatif. Penelitian lapangan itu sendiri memiliki sebuah tujuan untuk mempelajari secara intensif tentang latar belakang keadaan saat Ini dan interaksi lingkungan suatu unit sosial: individu, kelompok, lembaga atau masyarakat" (Creswell, 2016: 245). Teknik pengumpulan data meliputi kegiatan observasi (pengamatan), wawancara mendalam (indepth interview), studi pustaka dan penelusuran online. Teknik analisis data dilakukan sesuai dengan Model Analisis Interaktif (Miles \& Huberman, 1992). Model ini menjelaskan bahwa dalam pengumpulan data, peneliti selalu membuat reduksi data dan sajian data secara terus menerus sampai tersusun sebuah simpulan. Akan tetapi untuk berbagai data yang membutuhkan pengkodean atau kategori-kategori maka dipergunakan model Bogdan dan Biklen, misalnya, yaitu kode latar konteks, kode proses, kode aktivitas, kode peristiwa, kode strategi, kode hubungan dan struktur sosial, kode naratif, maupun kode metode (Emzir, 2012).

Adapun hal-hal yang dibahas dalam pembahasan artikel ini ialah mengenai program sosialisasi civic literacy yang dilakukan oleh Komunitas Dusun Binaan Mutiara Ilmu dan Solo Mengajar di Kota Surakarta, serta evaluasi penerapannya.

\section{PEMBAHASAN}

\section{Program Sosialisasi Civic literacy dalam Pembentukan Etika Warganegara Muda di Kota Surakarta}

Latar belakang ide sosialisasi civic literacy yang dilakukan oleh komunitas Dusun Binaan Mutiara Ilmu dan Komunitas Solo Mengajar di Kota Surakarta, dengan beberapa pertimbangan yaitu keprihatinan pada fenomena perkembangan teknologi informasi yang mengarah kepada hal negatif, ini disebabkan rendahnya literasi masyarakat dalam segala aspek, termasuk aspek pengetahuan kehidupan berwarganegara. Fenomena rendahnya 
peringkat literasi di Indonesia dan tingginya tingkat keaktifan masyarakat Indonesia di dunia maya (media sosial) juga merupakan fenomena menarik dan merupakan sebuah anomali.

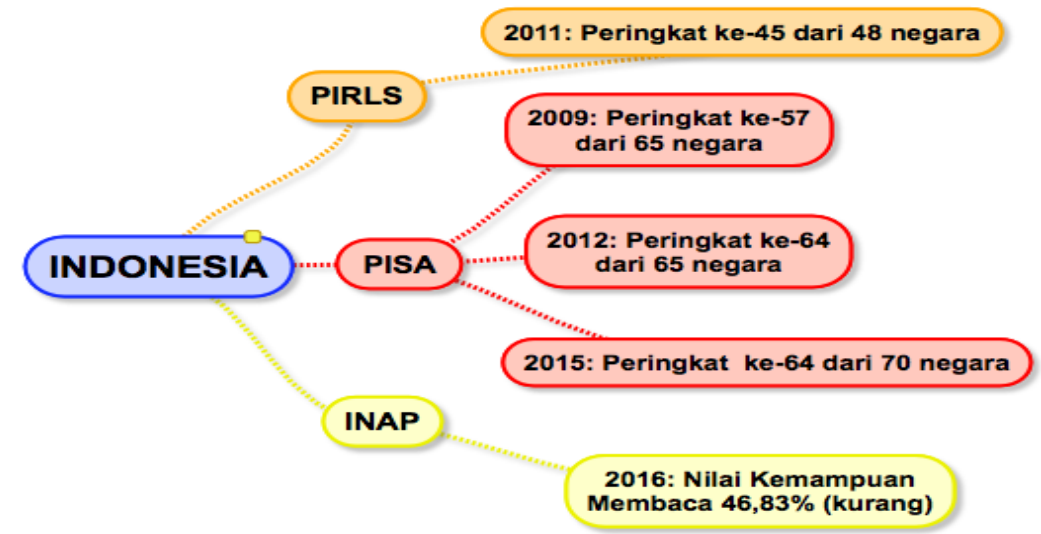

Gambar 1. Peringkat Literasi Indonesia (Sumber: APJII, 2016)

Perkembangan teknologi informasi memang tidak dapat dihindari, akan tetapi jika tidak memahami dan menguasai tentang perkembangan tersebut, masyarakat akan dengan mudah terbawa arus ke arah yang negatif seiring dengan perkembangan teknologi yang terus berlangsung. Dalam hal ini, dapat terlihat terkait dengan adanya permasalahan pada generasi muda dewasa ini.

Dimulai dari ketidakpedulian pemuda terhadap persoalan bangsa, masalah narkoba, pergaulan bebas, tawuran, sampai dengan permasalahan digital seperti mudahnya masyarakat dewasa ini mempercayai dan menyebar berita-berita hoax yang dibuat oleh oknum tertentu dengan tujuan tertentu pula. Hal tersebut yang kemudian memunculkan ide bagi beberapa organisasi volunteer pendidikan untuk berkontribusi di masyarakat dalam melakukan sosialisasi civic literacy. Pembelajaran dengan pendekatan informal, media dan metode yang sudah direncanakan, menjadi salah satu usaha belajar untuk diri sendiri serta "mempersiapkan" generasi muda supaya memiliki tingkat kemelekwacanaan kewarganegaraan (civic literacy) yang tinggi dan menjadi warganegara yang kritis dan memiliki kontribusi tertentu 
untuk membangun negara bangsa. Ada setidaknya tiga fase program sosialisasi civic literacy yang peneliti temukan di lapangan, yaitu:

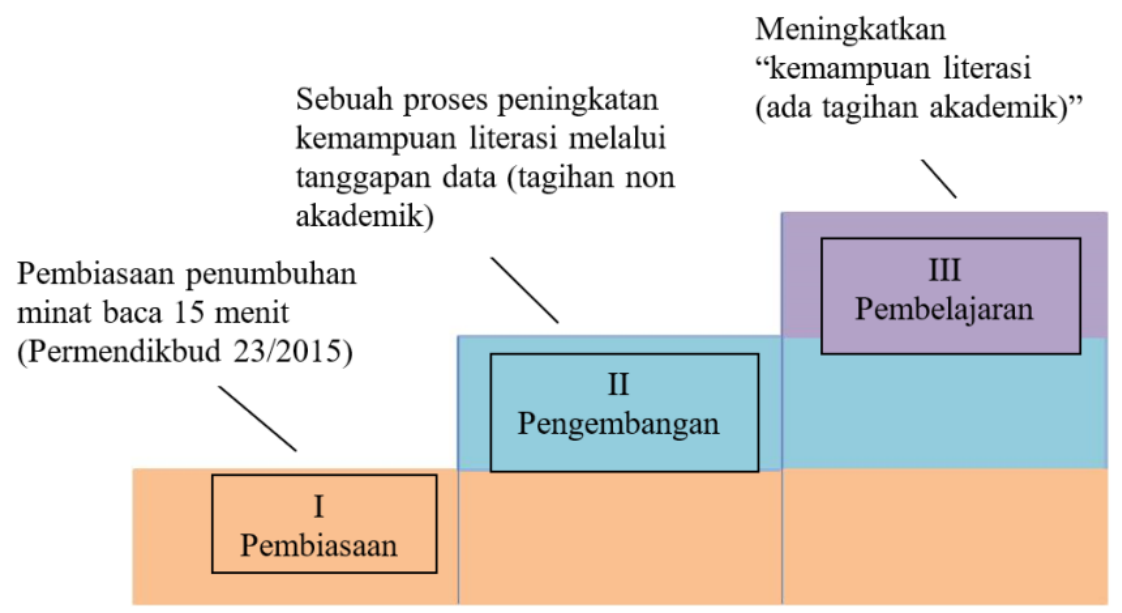

Gambar 2. Tingkatan Proses Program Sosialisasi Civic Literacy (Sumber: Diolah Peneliti, 2019)

Kegiatan sosialisasi civic literacy diawali dengan kegiatan penguatan literasi terkait "pengembangan 15 menit membaca", yaitu:

(i). Membaca secara Mandiri

(ii). Membaca Bersama-sama

(iii). Membaca secara terpandu

(iv). Saling Menceritakan Hasil Bacaan (berpasangan)

(v). Mengembangkan Tokoh

(vi). Menulis Artikel/ Pengalaman

(vii). Membuat Kelas Kaya Literasi (Sumber: Diolah Peneliti, 2019)

Model pembelajaran, khususnya dalam kajian pendidikan kewarganegaraan ialah bentuk atau grand desain pembelajaran dari awal sampai akhir yang disajikan secara khas (Murdiono, M., 2014). Adapun konteks model pembelajaran ialah sebuah wadah dari penerapan pendekatan, metode, dan teknik pembelajaran itu sendiri. Proses ini terangkum dalam kegiatan sosialisasi civic lietarcy yang mengarahkan pada perilaku warganegara muda yang beretika 
berdasarkan pengetahuan dan kemelek-wacanaan kewarganegaraan. Fungsinya ialah mengarahkan warganegara muda untuk membentuk good citizenship.

Kegiatan sosialisasi civic literacy terintegrasi dalam pendidikan Kewarganegaraan yang dilakukan oleh beberapa organisasi volunteer pendidikan di Surakarta. Observasi awal melihat berbagai perbedaan subtansi civic literacy yang dikembangkan oleh setiap organisasi volunteer pendidikan. Hasil observasi awal menunjukkan terjadi perbedaan dalam muatan subtansi civic literacy dari tiap organsiasi volunter pendidikan di Surakarta. Perilaku pengguna internet di Indonesia berdasarkan pada jenis konten yang diakses menunjukkan bahwa mayoritas pengguna melakukan akses internet pada konten media sosial sampai dengan tingkat persentase $97,4 \%$. Data tentang pengguna internet di Indonesia tersebut membuat pemikiran pemuda (volunteer) menjadi lebih rasional. Pengguna internet yang didominasi oleh usia muda dan mayoritas akses pada media sosial memunculkan pandangan bahwa menjadi penting untuk dapat memanfaatkan internet dan media sosial secara bijak, apa lagi dewasa ini merupakan era digital dan keterbukaan informasi sangat luas yang bahkan informasi yang dihimpun terutama dalam media sosial tidak jarang merupakan informasi yang tidak benar (hoax) terlebih informasi yang memiliki kepentingan khusus, tentang politik misalnya, informasi yang punya muatan kepentingan pemilihan kepala daerah (pilkada) yang kemudian disebarluaskan informasi tersebut melalui media sosial, dan diterima oleh masyarakat umum sebagai pengguna merupakan sebuah bentuk penyebaran informasi yang masif dewasa ini. Jika masyarakat tidak memiliki literasi yang tinggi terkait dengan informasi tersebut, maka bisa jadi masyarakat akan percaya dengan informasi yang dibuat oleh beberapa kalangan yang memiliki kepentingan tertentu. Hal ini yang kemudian menjadi dasar pemikiran pemuda berupaya untuk melakukan peran yang dapat mencegah terjadinya ketidaktahuan masyarakat terutama tentang kehidupan bermasyarakat, berbangsa dan bernegara. 


\section{Evaluasi Program Sosialisasi Civic literacy dalam \\ Pembentukan Etika Warganegara Muda di Kota Surakarta}

Sosialisasi kegiatan civic literacy yang dilakukan oleh komunitas Dusun Binaan Mutiara Ilmu dan Solo Mengajar memiliki tujuan utama untuk membentuk warganegara yang baik. Sosialisasi civic literacy dilaksanakan pada anak-anak rentang usia sekolah dasar, rupanya mereka memiliki tujuan untuk menyiapkan generasi penerus yang memiliki mental dan sikap warganegara yang baik dalam rangka kehidupan bermasyarakat, berbangsa dan bernegara ke depan. Kajian tentang warganegara dan kewarganegaraan selalu dikaitkan dengan pola perilaku masyarakat, bahwa warganegara dikatakan sebagai warganegara yang baik (good citizen), tentu saja memiliki kualifikasi tertentu agar dapat dikatakan sebagai warganegara yang baik (good citizen). Memiliki etika kehidupan berbangsa dengan bernegara merupakan bagian dari good citizen.

Berkaitan dengan etika Kewarganegaraan, Putri Kusuma, Volunteer Solo Mengajar, mengatakan bahwa "anak-anak Solo mengajar di sini itu memiliki prinsip toleransi yang kuat. Di sini ada agama Kristen, Islam, Katolik dapat menerima satu sama lain. Sikap toleransi antar siswa itu sudah menjadi prinsip, hal ini ditunjukkan dengan berperilaku santun, ramah, menjaga pertemanan, menghargai dan menghormati orang lain walaupun itu berbeda pendapat dan keyakinan, menjunjung tinggi harkat martabat manusia dengan hidup rukun, damai. Lebih lanjut ia mengatakan bahwa "Saya sudah lama di sini hampir tidak pernah ada penyimpangan intoleransi. Toleransi juga dibentuk lewat kegiatankegiatan belajar sambil bermain, yang menciptakan kerja sama, rasa saling menghargai dan menghormati pendapat seperti kegiatan kelas inspirasi, outbond, dan lain-lain".

Dengan demikian, dapat digambarkan bahwa evaluasi program sosialisasi civic lietarcy dari mulai input, proses dan output berupa dampak dan implikasinya, sebagai berikut: 


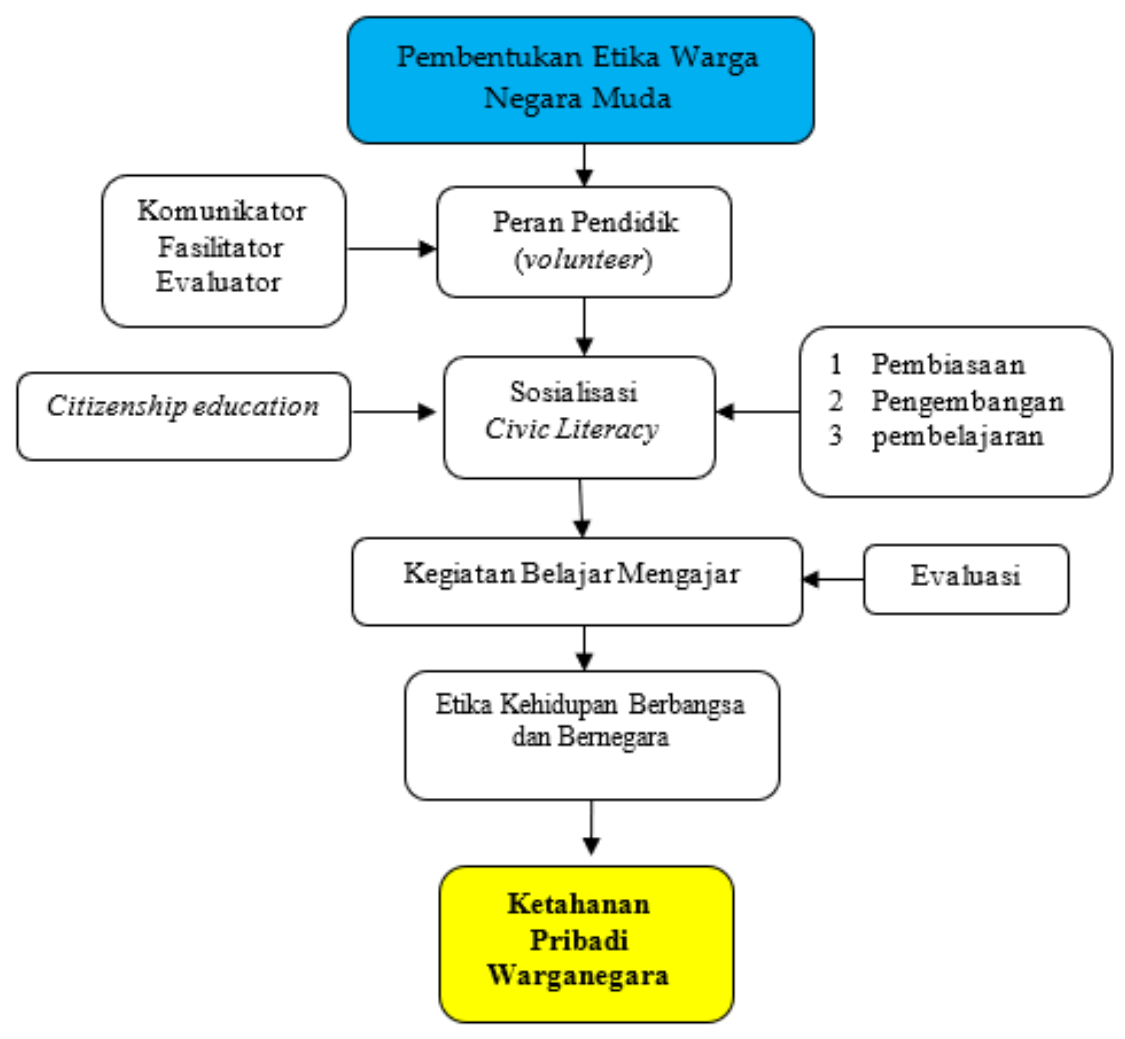

Gambar 3. Evaluasi Program Sosialisasi Civic Lietarcy dalam rangka Pembentukan Etika Warga Negara Muda (Sumber: Diolah Peneliti, 2019)

Berdasarkan wawancara dengan beberapa siswa Taman Belajar terkait dengan dampak civic literacy di Solo Mengajar, diperoleh data pola perilaku yang ada pada siswa, yaitu: (1) Tidak menghina dan mengolok-olok paham orang lain yang berbeda dengan saya; (2) menghargai perbedaan dalam menanggapi dan memahami hal-hal tertentu berlandaskan dasar negara Indonesia, yaitu Pancasila; dan (3) Menghormati perbedaan pendapat kaitannya dengan agama atau yang lain. Alasan ini penting untuk dilakukan, karena hidup dari tempat yang berbeda, sistem pendidikan keluarga yang berbeda, karakter yang berbeda dan daya pandang yang berbeda pula. Oleh karenanya, harus saling 
menghormati berdasarkan aturan yang telah ditentukan, aturan agama dan negara.

Hasil pengamatan lapangan, yaitu di Solo Mengajar dan Dusun Binaan Mutiara Ilmu menunjukkan bahwa peserta didik sudah memiliki sikap toleransi, hal tersebut dapat dibuktikan dengan berbicara santun dan sopan terhadap lain, saling menghargai dan menghormati pendapat teman pada saat kerja kelompok, saling menghormati dan menghargai teman pada saat diskusi materi pembelajaran, terjalinnya sikap saling menghargai dan menghormati antar peserta didik dengan kebiasaan berjabat tangan, terjalinnya keakraban sesama teman meskipun mempunyai perbedaan agama, suku, dan latar belakang.

Selanjutnya, berdasarkan wawancara yang dilakukan dengan beberapa pendidik dan peserta didik serta hasil observasi di atas, dapat disimpulkan bahwa peserta didik Solo Mengajar dan Dusun Binaan Mutiara Ilmu dapat dikatakan sudah memiliki Etika Kehidupan Berbangsa dan Bernegara. Hal ini direalisasikan dalam bentuk sikap dan tingkah laku, yaitu (1). Peserta didik saling menghargai dan menghormati terhadap perbedaan pendapat. Hal ini ditunjukkan dengan berbicara santun dan ramah terhadap perbedaan pendapat dan bersedia menerima saran dan masukan guru terhadap perbedaan pendapat.

(2). Peserta didik saling menghargai dan menghormati antar perbedaan agama, ditunjukkan dengan sikap tidak mengganggu, mengejek, atau mengolok-olok teman yang berbeda agama.

(3). Peserta didik saling hidup rukun dengan menjalin pertemanan yang baik tanpa membedakan agama, suku, dan latar belakangnya. Hal ini ditunjukkan dengan kebiasaan berjabat tangan antar siswa di lingkungan sekolah, tidak mendiskriminasi orang lain dan tidak membuat konflik atau kegaduhan di lingkungan sekolah.

(4). Peserta didik saling peduli terhadap teman dan masyarakat. Hal ini ditunjukkan peserta didik dengan menjenguk teman yang sakit, menjenguk teman yang sakit, ikut kegiatan peduli bencana dan kegiatan amal. 
Kegiatan sosialisasi civic literacy yang dilakukan di Kota Surakarta oleh Dusun Binaan Mutiara Ilmu dan Komunitas Solo Mengajar dapat dikatakan sebagai salah satu contoh yang konkret terkait dengan usaha pola pembentukan warganegara yang baik. proses yang dilakukan yaitu diawali dengan mendasari atau memberikan penanaman nilai pengetahuan kewarganegaraan atau yang disebut sebagai civic knowledge, kegiatan ini dilakukan melalui proses sosialisasi. kemudian dilakukan proses pelatihan keterampilan kewarganegaraan atau civic skill melalui metode pembalajaran bermain peran dalam konteks kewarganegaraan, dan kemudian diakhiri dengan proses penumbuhan sebuah sikap kewarganegaraan atau civic disposition melalui adanya pemberian tanggung jawab berupa sebuah tugas yang harus dikerjakan. Secara langsung maupun tidak langsung proses ini mengarahkan pada pembentukan etika dan karakter baik karakter privat maupun karakter publik.

Karakter privat itu sendiri dapat dibentuk melalui proses pemberian materi yang disosialisasikan, seperti halnya materi tentang sopan santun, yaitu sebuah materi yang memiliki substansi dan tujuan untuk membentuk rasa hormat warga negara, baik kepada dirinya sendiri maupun kepada orang lain. Kemudian ada materi tentang hak dan kewajiban warganegara, sebuah literasi tentang suatu hal yang harus diketahui untuk diimplementasikan setiap warganegara, dan materi-materi lain yang memiliki tujuan untuk menumbuhkan karakter privat seperti tanggung jawab, mandiri, disiplin, hormat, peduli, kreatif, kritis, dan lain-lain. Muaranya, karakter privat tersebut mengarah pada sebuah implementasi karakter publik, yaitu suatu bentuk ciri warganegara yang baik (good citizen) dalam rangka berhubungan dengan warganegara lain, maupun proses berhubungan dengan negara. Warganegara hendaknya memiliki sebuah kompetensi yang signifikan terkait dengan bagaimana proses berhubungan dengan warganegara lain, bagaimana melaksanakan kewajiban dan haknya, serta bagaimana cara mengimplementasikan sikap cinta terhadap tanah air. Karakter publik ini dapat dikatakan sebagai pola 
perilaku yang memiliki substansi sikap di ranah publik baik itu pola perilaku hubungan antar warganegara (horizontal) maupun pola perilaku hubungan warganegara dengan negara (vertikal).

Pola perilaku horizontal ini berisi konteks implementasi pemahaman tentang pola kehidupan sosial, yang maksudnya ialah warganegara itu tidak bisa hidup sendirian, melainkan tetap membutuhkan warganegara lainnya, utamanya dalam hal-hal yang memang membutuhkan kerja sama seperti menjaga fasilitas umum, menjaga ketertiban, dan sejenisnya. Adapun terkait dengan pola perilaku vertikal, secara sederhana dapat dipahami sebagai proses suatu sikap yang mengarah pada sense of belonging terhadap negara, sehingga kemudian muncul sikap nasionalisme, patriotisme, semangat bela negara, dan menjaga keutuhan bangsa. Penjelasan karakter privat dan karakter publik ini merupakan penjelasan sederhana mengenai warganegara yang baik dan ideal dalam sebuah negara. Adapun penguatan civic literacy merupakan salah satu upaya untuk menciptakan karakter tersebut.

Adanya keseimbangan karakter privat dan karakter publik ini mengarahkan pada kondisi dinamis ketahanan pribadi warganegara, dengan adanya tingkat literasi yang tinggi, maka masyarakat lebih paham dan mengerti apa saja yang harus dilakukan dan apa saja yang tidak perlu atau bahkan tidak boleh dilakukan demi menjaga ketahanan pribadinya sebagai warganegara. Ketahanan pribadi itu sendiri merupakan "sebuah wujud dari kerangka ketahanan nasional, yang ditentukan oleh kualitas sumber daya manusia atau insani yang patriotik-religius, yang mencakup kualitas intelektual, moral dan etika, kualitas kepemimpinan serta kualitas pengabdian" (Sunardi, 1998; Ermaya Suradinata dan Alex Dinuth, 2001:129-130).

Dalam memahami ketahanan pribadi, perlu dipahami mengenai kepribadian. Kepribadian itu sendiri ialah sebuah keterpaduan yang menyangkut aspek-aspek psikis seperti halnya kecerdasan, kemudian aspek sikap, moralitas, motif, minat, kemampuan, dan ada pula aspek-aspek jasmaniah seperti panca indera, postur tubuh, tinggi badan, berat badan, dan lain 
sebagainya. Kepribadian ini pada prinsipnya ialah keterpaduan antara yang psikis dan jasmaniah tersebut, sehingga kemudian dapat mempengaruhi pola tingkah laku manusia (Sukmadinata, 2003: 136). Artinya manusia dalam mengembangkan dirinya, dengan perasaannya, dengan budaya, dengan kehendaknya dengan badan dan jiwa kehendaknya sedemikian rupa sehingga "mencapai suatu tingkatan yang stabil yang tak mudah goyah dalam keadaan apapun juga dan serasi mengembangkan hubungan antara manusia sebagai pribadi dan masyarakat serta bangsa" (Soedarsono, 1997: 50). Warganegara yang memiliki ketahanan pribadi mengarahkan pada perilaku warganegara yang baik (good citizen), adanya program sosialisasi civic literacy ini juga tidak lepas dari tujuan untuk membentuk warganegara yang baik, yaitu melalui pembentukan etika warganegara muda, yang pada dasarnya merupakan generasi penerus bangsa yang pada akhirnya akan menerima estafet kepemimpinan dari generasi sebelumnya.

Etika warganegara pada prinsipnya dibentuk dan atau terbentuk melalui proses yang tidak singkat untuk kemudian memunculkan sikap kewarganegaraan yang ideal. Hal ini tidak dapat lepas dari nilai moral yang ada di lingkungannya. Muhtamar (2020: 146) menjelaskan bahwa "Persenyawaan kebenaran dan keilahiahan (doktrin moral) dan kebenaran manusiawi (rasionalitas hukum) dalam konstitusi modern, diasumsikan menjadi jalan keluar beragam krisis fundamental kehidupan manusia dalam peradaban modern. Hal ini sekaligus bermakna munculnya peluang mengenai simbiosis dari pandangan dunia yang berorientasi pada religiusitas dan pandangan dunia yang berorientasi pada sikap ilmiah. Adanya sebuah keterpaduan ini dapat menjadi kekuatan baru dalam sistem kehidupan masyarakat menghadapi berbagai permasalahan yang fundamental, pada saat ini maupun pada masa yang akan datang. Adapun etika terkait dengan kemantapan sikap warganegara yang ideal. dapat pula dipahami sebagai sebuah keutamaan sikap yang tidak cukup atau berhenti pada sebuah pengetahuan dalam jiwa manusia, tetapi harus dimunculkan dalam sebuah tindakan yang nyata. "Tidak 
cukup sampai di situ, melainkan perlu dijadikan sebuah habit atau kebiasaan yang dilakukan berulang dan terus menerus dan tanpa paksaan. Hal ini dikarenakan apabila ada tindakan baik yang dilakukan dengan paksaan, maka pada prinsipnya tidak akan mencapai sikap keutamaan moral yang sesungguhnya" (Panani, 2019: 295). Sedangkan budi pekerti luhur, secara prinsip tidak hanya mengenai perilaku baik saja akan tetapi dapat dikategorikan sebagai perilaku yang mulia. Artinya, dapat dikatakan lebih tinggi dari budi pekerti dalam konteks cakupannya, yang mana tidak hanya konteks persoalan tentang pengetahuan tata krama dan kesopanan. Seseorang bisa saja memiliki budi pekerti yang baik tetapi belum tentu memiliki budi yang luhur. Bagi kalangan penghayat budi luhur merupakan kesempurnaan hidup (Sumiyati \& Sumarwanto, 2017 :15). Program sosialisasi civic literacy ini dapat dikatakan dalam ruang lingkup proses pembentukan warganegara yang baik (good citizen). Konteksnya dalam hal ini ialah pembentukan etika warganegara muda yang disiapkan sebagai generasi penerus bangsa Indonesia di masa depan.

\section{SIMPULAN}

Pertama, program sosialisasi civic literacy yang dilakukan oleh komunitas Solo Mengajar dan Dusun Binaan Mutiara Ilmu mengarahkan peserta didik untuk memiliki Etika Kehidupan Berbangsa dan Bernegara dan mampu menunjukkan dalam bentuk tingkah laku, yaitu peserta didik saling menghargai dan menghormati terhadap perbedaan pendapat. Hal ini ditunjukkan dengan berbicara santun dan ramah terhadap perbedaan pendapat dan bersedia menerima saran dan masukan guru terhadap perbedaan pendapat. Peserta didik saling menghargai dan menghormati antar perbedaan agama, ditunjukkan dengan sikap tidak mengganggu, mengejek, atau mengolok-olok teman yang berbeda agama. Peserta didik saling hidup rukun dengan menjalin pertemanan yang baik tanpa membedakan agama, suku, dan latar belakangnya. Hal ini ditunjukkan dengan kebiasaan berjabat tangan antar siswa di lingkungan sekolah, tidak mendiskriminasi orang 
lain dan tidak membuat konflik atau kegaduhan di lingkungan sekolah. Peserta didik saling peduli terhadap teman dan masyarakat. Hal ini ditunjukkan peserta didik dengan menjenguk teman yang sakit, menjenguk teman yang sakit, ikut kegiatan peduli bencana dan kegiatan amal. Adapun evaluasi program yang dilakukan, yaitu ada pada proses pembelajaran di mana seharusnya tentor memiliki sebuah buku pedoman atau pegangan yang dijadikan sebagai acuan sistematis dilaksanakannya sosialisasi civic literacy, artinya tidak hanya asal sosialisasi saja. Misalkan perlu modul sebagai pegangan sekaligus untuk dapat dikembangkan setiap tahunnya.

Kedua, evaluasi program sosialisasi civic literacy dalam pembentukan etika warganegara muda di Kota Surakarta mengarahkan pada pola pembentukan warganegara yang baik, yaitu diawali dengan mendasari atau memberikan penanaman nilai pengetahuan kewarganegaraan atau yang disebut sebagai civic knowledge, kegiatan ini dilakukan melalui proses sosialisasi. kemudian dilakukan proses pelatihan keterampilan kewarganegaraan atau civic skill melalui metode pembelajaran bermain peran dalam konteks kewarganegaraan, dan kemudian diakhiri dengan proses penumbuhan sebuah sikap kewarganegaraan atau civic disposition melalui adanya pemberian tanggung jawab berupa sebuah tugas yang harus dikerjakan.. Adapun arah dari pembentukan warganegara yang baik yang dilakukan yaitu dengan menumbuhkan suatu karakter privat dan karakter publik warganegara yang merupakan suatu komponen terciptanya ketahanan pribadi warganegara.

Selanjutnya, dari simpulan yang telah dipaparkan, peneliti merekomendasikan: Pertama, perlunya buku pegangan sosialisasi civic literacy bagi tentor, berupa modul. Kedua, perlu dilakukan kajian strategi, metode, dan media pembelajaran yang lebih komprehensif dalam pelaksanaan sosialisasi civic literacy. Ketiga, kegiatan sosialisasi civic literacy sangat berpotensi untuk menjadi salah satu solusi untuk memperkuat ke keindonesiaan, sehingga dapat menjadi pilot project bagi komunitas-komunitas lain yang ada 
di Indonesia untuk melakukan sosialisasi civic literacy sebagai salah satu kegiatan dalam komunitasnya.

\section{DAFTAR PUSTAKA}

Adeney, F. (1988). Citizenship Ethics: Contributions of Classical Virtue Theory and Responsibility Ethics, Graduate Theological Union, U.M.I, Berkeley.

Arikunto, S. (1993). Manajemen Pengajaran Secara Manusiawi. Jakarta: Rineka Cipta.

Arikunto, S., \& Jabar, C, S, A. (2009). Evaluasi Program Pendidikan. Jakarta. Bumi Aksara.

Asosiasi Penyelenggara Jasa Internet Indonesia (APJII). (2016).

"Penetrasi \& Perilaku Pengguna Internet Indonesia, Jakarta: Polling Indonesia.

Astuti. (2015). Pemuda dan Orientasinya, <internet: http://nasional.kompas.com/ read/jajak-pendapatkompas-pemuda dan-orientasinya).

Azra, A. (2003). Pendidikan Kewarganegaraan (Civic Education): Demokrasi, Hak Asasi Manusia dan Masyarakat Madani, Jakarta: Prenada Media.

Ch. Baroroh \& Al Rasyid, M. (2015). Constitutional Question

Sebagai Model Pembelajaran Kritis Untuk Pengembangan Civic Literacy Calon Guru Dalam Rangka Pembentukan Living Constitution, PUPT: Universitas Sebelas Maret.

Creswell, J. W. (2016). Research Design: Pendekatan Metode Kualitatif, Kuantitatif, dan Campuran Edisi Keempat. Yogyakarta: Pustaka Pelajar.

Branson, M. S. (1999). Belajar Civic Education dari Amerika, Yogyakarta: LKIS

Budimansyah, D. (2008). “Tantangan Globalisasi Terhadap Pembinaan Wawasan Kebangsaan dan Cinta Tanah Air Di Sekolah, Makalah SPS UPI Bandung.

Cholisin. (2010). "Penerapan Civic Skills Dan Civic Dispositions DalamMata Kuliah Prodi Pkn", Makalah, Disampaikan dalam Diskusi Terbatas Jurusan PKn dan Hukum FISE, UNY, 
25 September2010

Dwipayana, A. (2013). "Civic literacy", Naskah Combine, Maret 2013, Fisipol UGM.

Emzir, (2012). Metodologi Penelitian Kualitatif, Analisa Data, Jakarta: Rajawali Pers.

Miles, Matthew B. \& Michael, H. A. (1992). Analisis Data Kualitatif, Jakarta: Universitas Indonesia Press.

Muhtamar, S. (2020). Dikotomi Moral Dan Hukum Sebagai Problem Epistemologis Dalam Konstitusi Modern. Jurnal Filsafat, ISSN: 0853-1870 (print); 2528-6811(online)Vol. 30, No. 1 (2020), p. 123-149, doi:10.22146/jf.42562

Murdiono, M. (2014). "Pendidikan Kewarganegaraan Untuk

Membangun Wawasan Global Warganegara Muda", Jurnal

Cakrawala Pendidikan, Oktober 2014, Th. XXXIII, No. 3.

Nuryadi, M. H. (2010). “Peran Nilai-Nilai Dalam Kurikulum

Pendidikan Kewarganegaraan Untuk Membentuk

Masyarakat Madani Dan Implikasinya Terhadap

Ketahanan Sosial: Studi Tentang Pandangan Tenaga

Pendidik di Kecamatan Jebres, Kota Surakarta, Provinsi

Jawa Tengah", Tesis: Universitas GadjahMada.

Panani, S. Y. P. (2019). Seratwulang Reh: Ajarankeutamaan Moralmembangun Pribadi yang Luhur. Jurnal Filsafat, ISSN: 0853-1870 (print); 2528-6811(online)Vol. 29, No. 2(2019), p.275-299,doi:10.22146/jf.47373

Rahmaniyah, I. (2010). Pendidikan Etika Konsep Jiwa dan Etika.

Prespektif Ibnu Maskawaih, Malang: Aditya Media

Ruhulessin, J. C. (2019). Paradigma Etika Publik dalam Kearifan Lokal

Pela. Jurnal Filsafat, ISSN: 0853-1870 (print); 2528 6811(online)Vol. 29, No. 2(2019), p.183-205, doi:10.22146/jf.36344.

Soedarsono, S. (1997). Ketahanan Pribadi dan Ketahanan Keluarga Sebagai Tumpuan Ketahanan Nasional. Jakarta: PT Intermasa.

Sukmadinata, N. S. (2003). Landasan Psikologi Proses Pendidikan, Bandung: Remaja Rosdakarya.

Sumiyati \& Sumarwanto. (2017). Modul II Budi Pekerti Pendidikan 
dan Latihan Jabatan Penyuluhan Kepercayaan Terhadap tuhan Yang Maha Esa. Direktorat Jenderal Kebudayaan.

Kementerian Pendidikan dan Kebudayaan: Jakarta.

Sunardi. (1998). Teori Ketahanan Nasional. Yogyakarta: HASTANNAS

Suradinata, E. \& Alex D. (2001). Geopolitik dan Konsepsi Ketahanan Nasional. Jakarta: PT. Paradigma Cipta Yatsigama Suryadi, K., (2010), "Inovasi Nilai dan Fungsi Komunikasi Partai PolitikBagi Penguatan Civic literacy", Naskah Pidato "Pengukuhan Jabatan Guru Besar Ilmu Komunikasi Politik Pada Fakultas Pendidikan Ilmu Pengetahuan Sosial Bandung, 24 November 2010".

UNFPA Indonesia. (2014). "Monograph Series: Youth in Indonesia", Jakarta UNFPA Indonesia.

Wuryan, S., \& Syaifullah, (2008), Ilmu Kewarganegaraan (Civics), Bandung: Laboratorium Pendidikan Kewarganegaraan, UPI. 